\title{
Numerical modeling of the geothermal hydrology of the Volcanic Island of Basse-Terre, Guadeloupe
}

\author{
Margaux Raguenel ${ }^{1 *}$ (D), Thomas Driesner ${ }^{2}$ and François Bonneau ${ }^{1}$
}

*Correspondence:
margaux.
raguenel@univ-lorraine.fr
${ }^{1}$ Université de Lorraine,
CNRS, GeoRessources,
ENSG - 2 Rue du Doyen
Marcel Roubault, BP 10162,
54505 Vandoeuvre-lès-Nancy
Cedex, France
Full list of author information
is available at the end of the
article

*Correspondence:

margaux

1 Université de Lorraine

CNRS, GeoRessources,

ENSG - 2 Rue du Doyen

Marcel Roubault, BP 10162

oeuvre-lès-Nancy

Full list of author information article

\begin{abstract}
This study investigates the thermo-hydraulic implications of three geologic scenarios for characterizing the geothermal hydrology of Basse-Terre Island, Guadeloupe. Despite newly acquired magnetotelluric, petrophysical, and geologic data, flow patterns and heat sources have remained elusive. Our simulations were performed in 2D, on a cross section going from La Soufrière volcano in the south to the operating Bouillante geothermal field near the west coast. Simulation results are compared to geologic constraints such as the temperature profile measured at Bouillante and the timing of volcanic activity in the area, which may be indicative of new heat sources at depth. The simulations indicate that during lateral flow from La Soufrière, geothermal fluids would cool too much to explain the temperature at Bouillante. Two other scenarios were found to explain the current thermal structure of the Bouillante geothermal system: a young (ca. 5000 years) and more local magmatic intrusion at depth, or vertical corridors of enhanced permeability that tap hot and porous formations at a few $\mathrm{km}$ depth. Without further geologic evidence, neither of these two scenarios can be preferred. The second magma chamber scenario would indicate a more complex magmatic history of the island than previously established. The study shows that geologically constrained scenarios of regional geothermal hydrology can be meaningfully tested with current numerical simulation techniques, providing further insights for geothermal exploration.
\end{abstract}

Keywords: La Soufrière de Guadeloupe, High-enthalpy geothermal system, Numerical simulations

\section{Introduction}

Basse-Terre island in Guadeloupe (French West Indies) is part of the Lesser Antilles volcanic arc and has good potential for high-enthalpy geothermal resources (Laplaige et al. 2013). A geothermal plant was installed in 1984 at the Bouillante site on the island's west coast (Jaud and Lamethe 1985), where surface hot springs had indicated a possible high-enthalpy resource. This plant has now a production capacity of 15 MWe. The rest of the island, however, remained largely unexplored for geothermal resources. In recent years, several projects have been launched to determine the potential of other targets 
in the area, such as GEOTREF, ${ }^{1}$ which focuses on the southwestern part of Basse-Terre. As for many geothermal greenfield exploration projects, characterization began with a magnetotellurics (MT) survey. The MT survey revealed several areas of interest (Teranov 2018) but could not identify clear targets. Due to intense vegetation cover and the collapse of La Soufrière volcano flanks, few geothermal features have been identified and MT anomalies may be related to extinct geothermal systems active during earlier phase in the complex volcanic history. A link between scattered thermal springs and the MT anomalies is not obvious.

We, therefore, performed a series of numerical simulations to better understand the geothermal hydrology of the Basse Terre system. We started from three geologic-geothermal scenarios developed by the GEOTREF project and compared the simulation results to known geologic and geothermal constraints, such as the site and thermal structure of the Bouillante system and the temporal evolution of volcanism, a possible indicator of new magmatic heat sources.

\section{Thermo-hydrology of high-enthalpy systems}

Numerical simulations over the past ca. 20 years have shown that the occurrence and the thermal and hydraulic characteristics of typical high-enthalpy geothermal systems are strongly and sensitively linked to a rather small parameter space. Strong feedbacks between geologic factors, heat transfer physics, and temperature-pressure-dependent water properties strongly limit the number of possible thermal structures (Driesner and Geiger 2007; Hayba and Ingebritsen 1997; Hurwitz et al. 2003; Scott et al. 2016).

A key finding of those studies is that the maximum temperature of a high-enthalpy system is ultimately governed by the competition of conduction-limited heat transfer in and near the magmatic heat source and advective heat transport by the geothermal fluid (Driesner and Geiger 2007): high host rock permeability allows high convection rates. While heat input from the magmatic heat source is conduction limited and, therefore, restricted to a relatively small range of values, convection rates scale with permeability that can vary over orders of magnitude. Fluids with high convection rates in permeable rocks, therefore, get heated less than those in less permeable rocks. Temperatures in systems with a bulk host rock permeability around $10^{-14} \mathrm{~m}^{2}(10 \mathrm{mD})$ typically cannot become hotter than ca. $250^{\circ} \mathrm{C}$, with boiling restricted to the upper few hundred meters; those with permeability ca. $10^{-15} \mathrm{~m}^{2}(1 \mathrm{mD})$ or slightly less will follow the boiling curve to great depth, reaching ca. $300^{\circ} \mathrm{C}$ at ca. $1 \mathrm{~km}$ depth; and those with permeability $10^{-16} \mathrm{~m}^{2}(0.1 \mathrm{mD})$ or less will develop no significant geothermal system, as the low permeability limits advection too strongly. This means that a rather small variation in large-scale mean host rock permeability leads to very different thermal characteristics of the geothermal system.

Obviously, site-specific geology like strongly fracture-bound flow, or inflow from aquifers, can modify the geometry of the system, but these temperatures are upper limits governed by thermodynamics and fluid flow. In this study, we attempt to utilize this overall sensitivity of geothermal systems to bulk permeability. The strong coupling between the

\footnotetext{
${ }^{1}$ http://geotref.com/.
} 
geologic situation and underlying physics in shaping geothermal systems implies thatunlike for cold groundwater systems with typically strong non-uniqueness-numerical simulations should be able to provide a meaningful test of the plausibility of conceptual models. We explore three different, geology-inspired thermo-hydrological models for the Bouillante system. If clear conclusions can be drawn about their physical plausibility, the findings of this study may aid to refine regional geothermal exploration models.

\section{Geological and geothermal context}

\section{General context}

As a part of the Lesser Antilles subduction system, the Guadeloupe archipelago is at the collision between the Caribbean and the North American plates. The volcanic arc resulting from the subduction is split at this location (Bouysse et al. 1990; Legendre 2018). The external arc (blue in Fig. 1a) is inactive, whereas the internal arc is still active (red in Fig. 1a). The succession of volcanic episodes on Basse Terre island has been reconstructed by several authors (Legendre 2012; Ricci et al. 2017; Samper 2007). The earliest volcanic events are located in the north of the island (Fig. 1b) and the volcanic centers become progressively younger towards the currently active volcanic center, La Soufrière in the south. Based on these relations and the results of the MT surveys, a cross section was selected for this study that crosses three volcanic complexes (Fig. 2): the Axial Chain, which was active between 1,000,000 and 435,000 years ago, the Bouillante Chain, which was active between 850,000 and 250,000 years ago, and the Grande-DécouverteSoufrière complex, which began activity 205,000 years ago and is still active.

\section{Geologic elements of geothermal relevance}

The earlier magmatic phases may still retain residual heat and are considered as one factor explaining the geothermal potential of the area (Boudon et al. 2008; Legendre 2012; Zlotnicki et al. 1992).

La Soufrière is an active volcano, and its inferred, underlying magma chamber likely provides a strong and active heat source (Lachassagne et al. 2009). The composition of the magma is rather silicic, and the temperature of the magma chamber has been estimated as around $800^{\circ} \mathrm{C}$ by Besson and Poirier (1994). However, its depth and size are still uncertain. The large distance $(15 \mathrm{~km})$ between La Soufrière and the Bouillante geothermal system, as well as the location of Bouillante in the older, extinct volcanic areas, has sparked discussions whether regarding there is a second, hidden magmatic heat source below the Bouillante system that has no associated volcanic features and does not follow the north-south age trend (Calcagno et al. 2012).

Another important factor potentially affecting geothermal activity in the Lesser Antilles, and especially in Guadeloupe, is the presence of a dense fault network allowing the circulation of fluids at depth. In Basse-Terre Island, two major fault families have been identified (Fig. 1b) (Feuillet et al. 2002): 

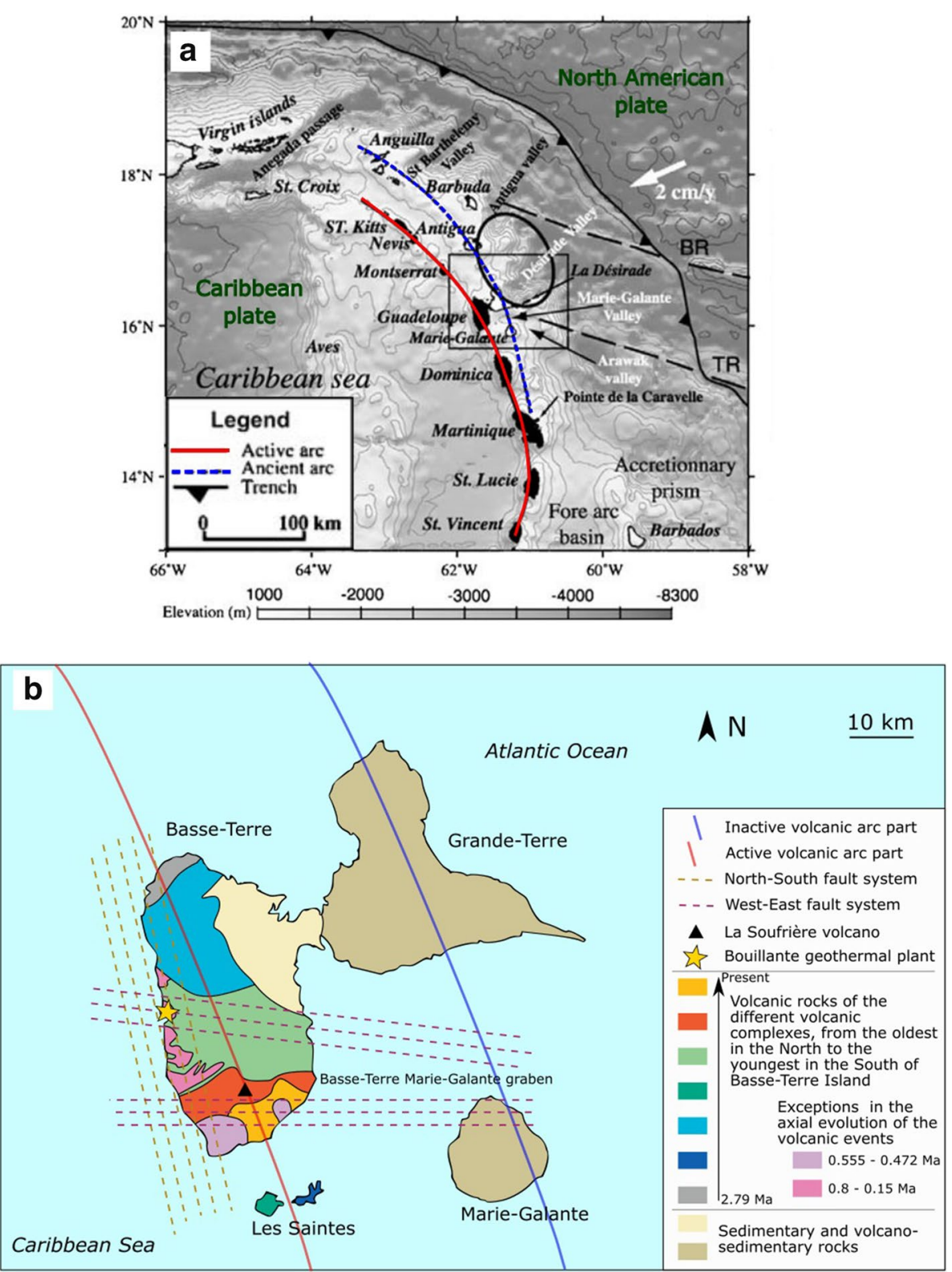

Fig. 1 Geological context of the Guadeloupe archipelago. a Volcanic arc resulting from the subduction of the Caribbean plate under the North American plate at a rate of $2 \mathrm{~cm} /$ year (modified from Feuillet et al. 2002; Lachassagne et al. 2009). b Lithology and fault network in the Guadeloupe archipelago, with volcanic units identified on Basse-Terre (modified from Komorowski et al. 2005; Lachassagne et al. 2009)

- A west-east oriented family, corresponding to an extensional regime that is reflected by the presence of the Basse-Terre-Marie-Galante graben in the southern part of the island (purple lines in Fig. 1b).

- A north-south oriented family, corresponding to normal faults that are part of the Basse-Terre-Montserrat system that extends throughout the volcanic arc (orange lines in Fig. 1b). 


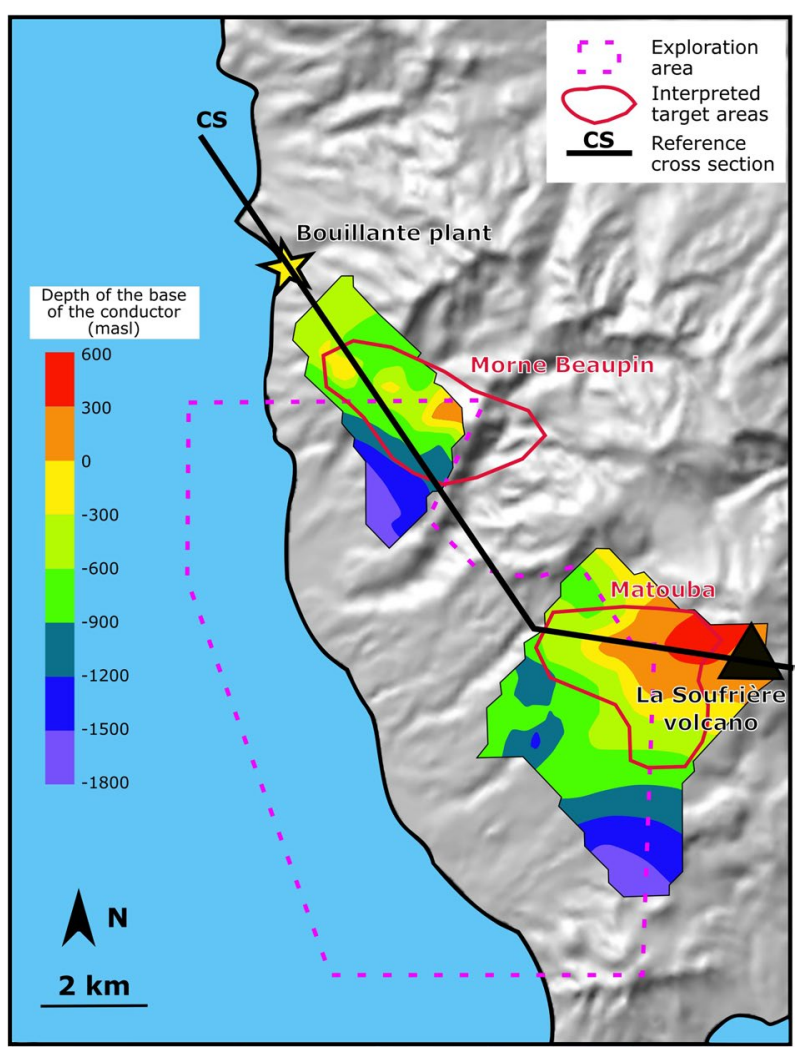

Fig. 2 Map of the southwest part of Basse-Terre, showing the areas of interest determined from the MT survey. The black line represents the cross section used for this study (modified from Teranov 2018)

These two fault systems are identified at various scales, with faults observed at lengths of several kilometers and fractures observed on outcrops or rock samples.

In general, the global behavior of the geothermal system and the role of these different elements have remained poorly understood.

\section{Constraints on the geothermal reservoir of the south of Basse-Terre Island}

The present study was inspired by the results of a magnetotelluric survey that was run in the context of the GEOTREF project in 2015-2016. The data were acquired by the Teranov and Imagir companies from 149 stations, with 103 obtaining high quality data. The stations were not evenly spaced, due to the presence of anthropogenic activity or accessibility issues. The acquired data were analysed to produce 1D and 3D models (Teranov 2018). Two areas with low resistivity were identified in the area of interest, near Matouba and Morne Beaupin (Fig. 2). In light of their geometries (dome shape, high vertical resistivity contrast and thin conductive layer), these two low resistivity areas may represent clay caps above active geothermal reservoirs (Fig. 2; Navelot 2018; Teranov 2018). However, they may also represent remnant clay caps above extinct geothermal systems. Therefore, a resistivity cross section has been extracted from the 3D model, passing through the MT anomalies as well as La Soufrière volcano and Bouillante (black line Fig. 2). This cross section defines our numerical simulation domains and allows us to test for plausibility of active hot 


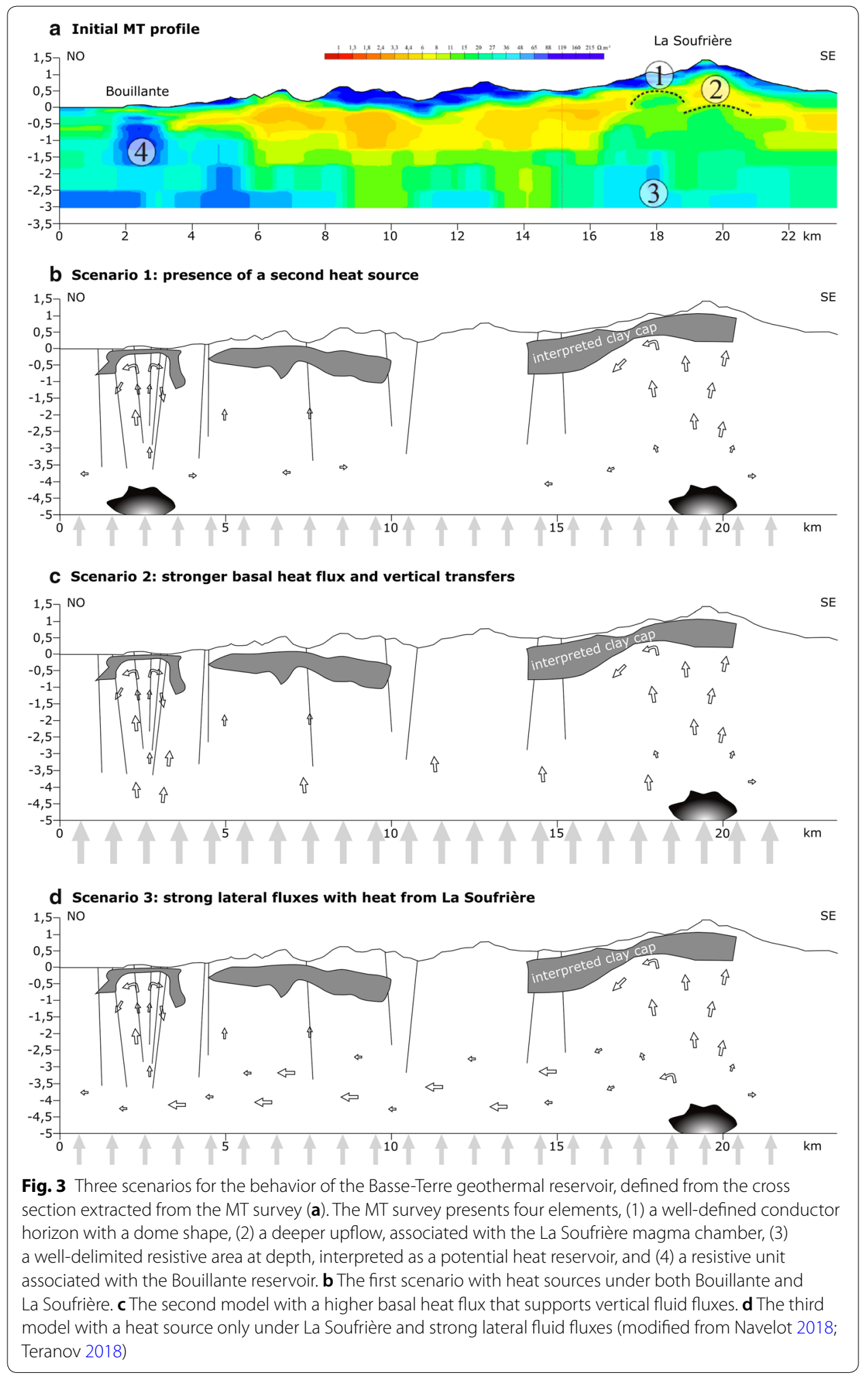

upflow in these regions (Fig. 3a). The 2D modeling has been chosen as it allows to define geological scenarios with a restricted number of parameters, considering the uncertainties remaining in the global 3D geological model. 

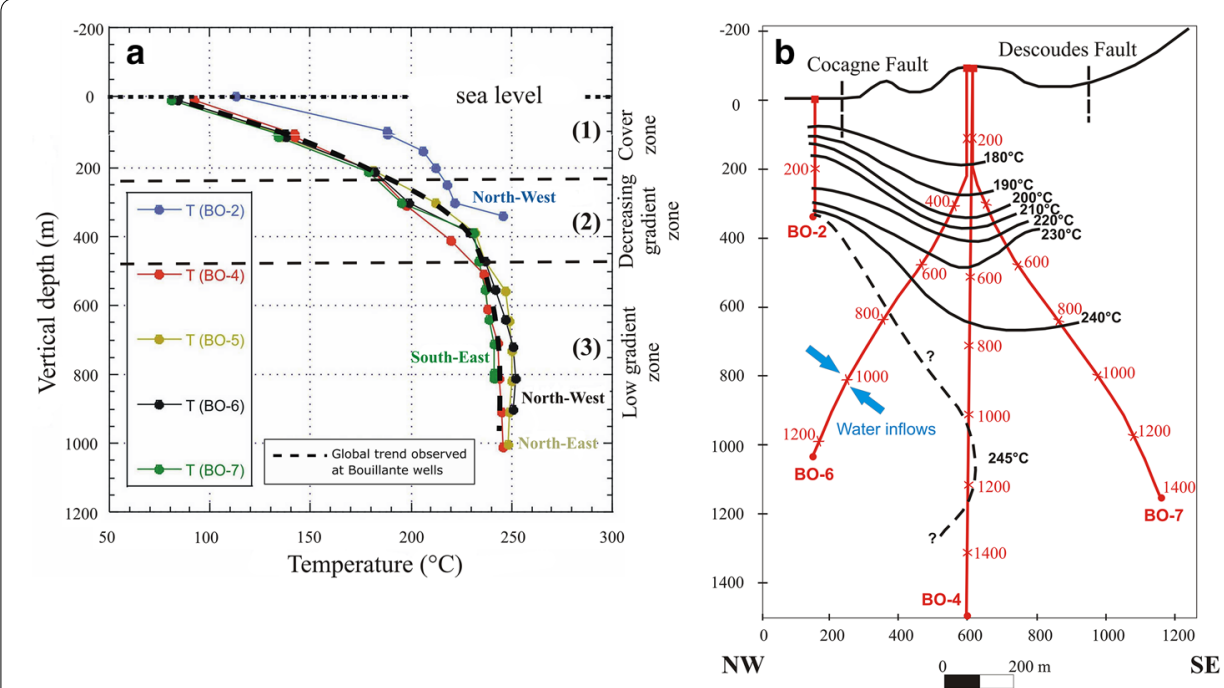

Fig. 4 Well data from Bouillante. a Equilibrium temperature-depth profiles in the main Bouillante boreholes and $\mathbf{b}$ isotherms in a NW-SE plane (modified from Guillou-Frottier 2003)

Four interesting elements are observed on this resistivity cross section: a welldefined conductor horizon with a dome shape [(1) in Fig. 3a], a deeper upflow associated with the La Soufrière magma chamber [(2) in Fig. 3a], a well-delimited low resistivity area at depth, interpreted as a potential geothermal reservoir [(3) in Fig. 3a], and a low resistivity unit associated with the Bouillante reservoir [(4) in Fig. 3a].

From this resistivity cross section, three different conceptual scenarios have been defined by the GEOTREF project. These scenarios vary mainly regarding the nature of the heat sources involved. They all seek to justify both the temperature profiles at Bouillante (Fig. 4) and the MT anomalies (Fig. 3):

Scenario 1: Presence of a second heat source. This scenario suggests that the Bouillante reservoir is mainly heated by an underlying, cooling magma chamber (Fig. 3b).

Scenario 2: Large basal heat flux and vertical conduits. This scenario suggests that the basal heat flux is strong enough to heat the Bouillante area through sub-vertical fault conduits that provide pathways for heat and fluid flow (Fig. 3c).

Scenario 3: Dominance of horizontal heat transport. In this scenario, the La Soufrière magma chamber is considered to be the primary heat source. Heat and fluids move laterally through horizontal zones corresponding to volcanic aquifers and a permeable zone at the ductile-brittle transition temperature.

Scenarios $2+3$ : Combination of scenarios 2 and 3. In this scenario, the La Soufrière magma chamber is considered to be the primary heat source. Heat and fluids move laterally through the previously defined horizontal zones and ultimately the subvertical fault conduits (Fig. 3d). 


\section{From geology to numerical simulations}

\section{Choice of the simulator}

The three scenarios present constraints that cannot be handled by many numerical simulation tools, such as the explicit inclusion of a magmatic heat source (here taken as $800^{\circ} \mathrm{C}$ ) and phase changes (liquid, vapor or supercritical water). At present, the HYDROTHERM code of the USGS (Hayba and Ingebritsen 1994, 1997; Kipp et al. 2008), the Complex Systems Modeling Platform (CSMP++) (Matthaï 2014; Matthaï et al. 2007) and a module of THOUGH2, iTOUGH2-EOS1sc (Magnusdottir and Finsterle 2015) are able to perform such simulations routinely. As discussed by Ingebritsen et al. (2010), CSMP ++ presents the advantages of dealing with multiphase flow and geometrically complex geological structures through unstructured grids (Paluszny et al. 2007; Patterson et al. 2018; Yapparova et al. 2014) and elaborates a coupled Control Volume-Finite Element resolution scheme (Weis et al. 2014), whereas HYDROTHERM performs computations on structured grids with a finite difference approach (Hayba and Ingebritsen 1994; Kipp et al. 2008). Both codes have provided essentially identical results for similar model setups except for minor discretization-specific differences (Weis et al. 2014).

As HYDROTHERM has an easy-to-use interface and model workflow, first tests were run with this tool, but only rarely converged, due to high differences in the permeability values. CSMP ++ was, therefore, used to investigate the scenarios further. A refined study of the factors governing the thermal structure of the Bouillante system was done in HYDROTHERM, as a large set of pre-existing results with this tool (Driesner and Geiger 2007; Hayba and Ingebritsen 1997) allowed rapid narrowing down of the relevant parameters.

For the purposes of this study, we developed a novel workflow that allowed us to extract cross sections from the 3D geomodeller SKUA-Gocad, repair them if needed (Anquez et al. 2019), mesh them, and finally transfer all the required information to CSMP ++ (geological entities, petrophysical properties, boundary conditions, etc). A SKUA-Gocad model was built based on the topography of the area and the structural interpretations done by the GEOTREF geologists (Teranov 2017).

The CSMP++ implementation used to describe the fluid flows and thermal evolution of the system was developed by Weis et al. (2014), and uses the Control Volume Finite Element Method to solve the equations.

\section{Parametrization of the model}

The model parametrization should describe both the heat source and the geological heterogeneities that impact fluid flow and heat transfer. Establishing such parametrization is challenging, both in terms of the initial choice of parameters to describe the system at the appropriate scale and in uncertainty management of parameter values. We ran a preliminary study to assess the sensitivity to the topography, the precipitation flux and geological heterogeneities (Raguenel et al. 2017). This work showed that topography needs to be carefully represented, but that the infiltration from rainfall has a limited impact on the simulation for this area. This is in accordance with several local studies that show that the volcano edifice presents a collapse, which controls fluid flows and limits them to the upper part of the volcano (Brothelande et al. 2014; Gaudin et al. 2015; 


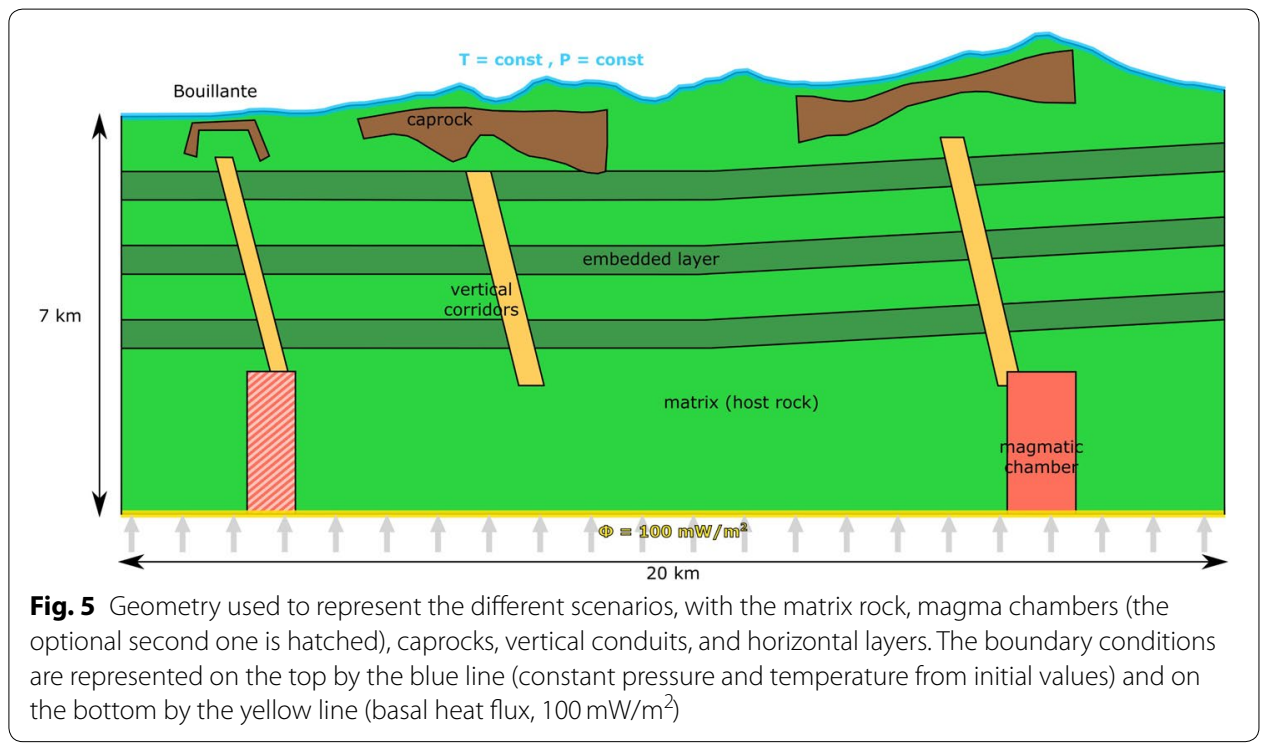

Rosas-Carbajal et al. 2016). The geological heterogeneities have a major impact on the simulation. In this study, we intend to quantify the impact of the main geological structures described in "Geological and geothermal context".

Figure 5 describes the simplified rock types that we used to represent subsurface heterogeneities. We define five rock types with petrophysical properties that follow the findings of Navelot et al. (2018). The following three rock types are used to define the base geology of the model:

- Intrusion. The magmatic intrusion is represented by impermeable rock $\left(10^{-22} \mathrm{~m}^{2}\right)$ at the beginning of the simulations. The permeability then evolves depending on the temperature (Hayba and Ingebritsen 1997). The initial temperature of this intrusion is $800^{\circ} \mathrm{C}$ (Besson and Poirier 1994). The size and depth of the intrusion were fixed at plausible values, and the effect of the relatively high uncertainties about these parameters was not studied further. However, the number of magmatic sources included in the model can vary (1 or 2 intrusions).

- Caprock. This rock type represents the clay caps suggested by the MT data. These rocks have low permeability $\left(10^{-18} \mathrm{~m}^{2}\right)$. Lacking adequate constraints, we decided not to implement a function that would allow the caprock to evolve as a function of time as the geothermal system develops.

- Matrix. This rock type is the most widespread. Its porosity is fixed at 0.3 while its permeability is temperature dependent (Hayba and Ingebritsen 1997), varying from $10^{-15}$ to $10^{-18} \mathrm{~m}^{2}$.

GEOTREF geologists suggested large-scale horizontal and vertical flow in geological structures. Two other optional rock types were defined to integrate these concepts according to the scenarios introduced in Fig. 3.

- Higher permeability layers. To represent potentially strong lateral fluxes, three higher permeability horizontal layers were embedded in the matrix rock $\left(5 \cdot 10^{-14} \mathrm{~m}^{2}\right)$. 
- Fault conduits were represented by a similarly high permeability $\left(5 \cdot 10^{-14} \mathrm{~m}^{2}\right)$.

Initial and boundary conditions represent other physical constraints on the model. On the bottom of the model, a basal heat flux is represented with a value of $100 \mathrm{~mW} / \mathrm{m}^{2}$ (Manga et al. 2012). On the top of the model, we decided to maintain the initial conditions at atmospheric pressure and temperature as the precipitation flux has a negligible impact on the simulation (Raguenel et al. 2017). The lateral boundaries of the model are free flow boundaries.

\section{Sensitivity study with a sub-model for a separate magmatic heat source under Bouillante}

Only a few simulations with a separate heat source below the Bouillante system converged using either HYDROTHERM or CSMP++. We, therefore, ran a separate sensitivity study using the simple single-intrusion setup of Hayba and Ingebritsen (1997) with one non-permeable layer above the intrusion. The low-temperature end $\left(<360^{\circ} \mathrm{C}\right)$ of the temperature-dependent permeability model of Hayba and Ingebritsen (1997) for the "matrix" permeability was varied between $5 \cdot 10^{-14} \mathrm{~m}^{2}$ and $10^{-15} \mathrm{~m}^{2}$ to a demonstrate consistency with the full model setup using $10^{-15} \mathrm{~m}^{2}$ and (b) more closely constrain the most likely permeability. A $300 \mathrm{~m}$ thick and $600 \mathrm{~m}$ wide caprock with a permeability of $10^{-18} \mathrm{~m}^{2}$ was placed at the surface above the intrusion. A thermal boundary condition of constant $80^{\circ} \mathrm{C}$ in the uppermost cells of this caprock turned out to be essential to reproduce the upper parts of the measured temperature profiles.

\section{Results}

\section{General thermal structure}

The simulation corresponding to the first scenario (Fig. 3b), with a second magma chamber under Bouillante, develops two well-defined thermal plumes (Fig. 6a) above the two heat sources. No additional upwellings develop.

The simulation corresponding to the second scenario, which enhances vertical heat transport via high-permeability conduits, shows three upflow zones sustained by the basal heat flux and La Soufrière magma chamber (Fig. 6b).

The simulation representing the third scenario, with a single strong heat source at La Soufrière and enhanced lateral fluid flow, does not result in clearly defined hot zones (Fig. 6c).

A fourth simulation, combining the second and third scenarios with the enhancement of both lateral and vertical fluid fluxes, also results in diffuse and unclear hot zones (Fig. 6d). Moreover, the middle vertical conduit, which brought hot fluids to the surface under the second scenario, now conveys cold fluids from the surface.

\section{Thermal structure at the Bouillante site}

Temperature profiles were extracted from each simulation result at the location of Bouillante (red well, Fig. 6). Figure 7 compares every simulated temperature profiles with data measured at Bouillante (Guillou-Frottier 2003). The models in which fluid flow is influenced by horizontal layers present lower temperatures.

The two scenarios with a second magma chamber and permeable vertical conduits seem to reproduce the thermal profile at Bouillante most closely. To assess transient 


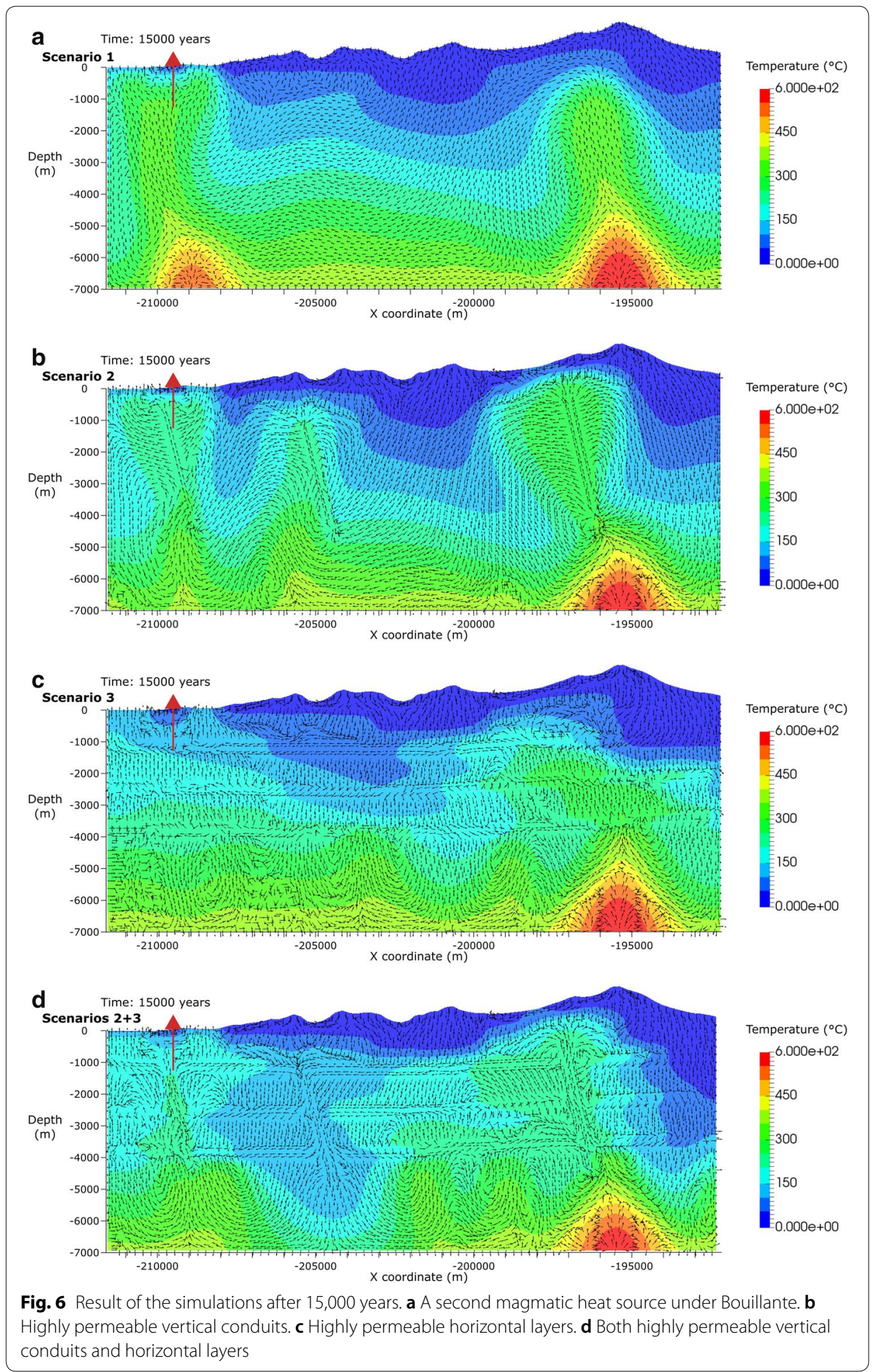

effects, we also extracted temperature profiles at several different simulation times for the scenarios with a second magma chamber (Scenario 1, Fig. 8a) and highly permeable vertical conduits (Scenario 2, Fig. 8b). In each case, we observe that the peak 


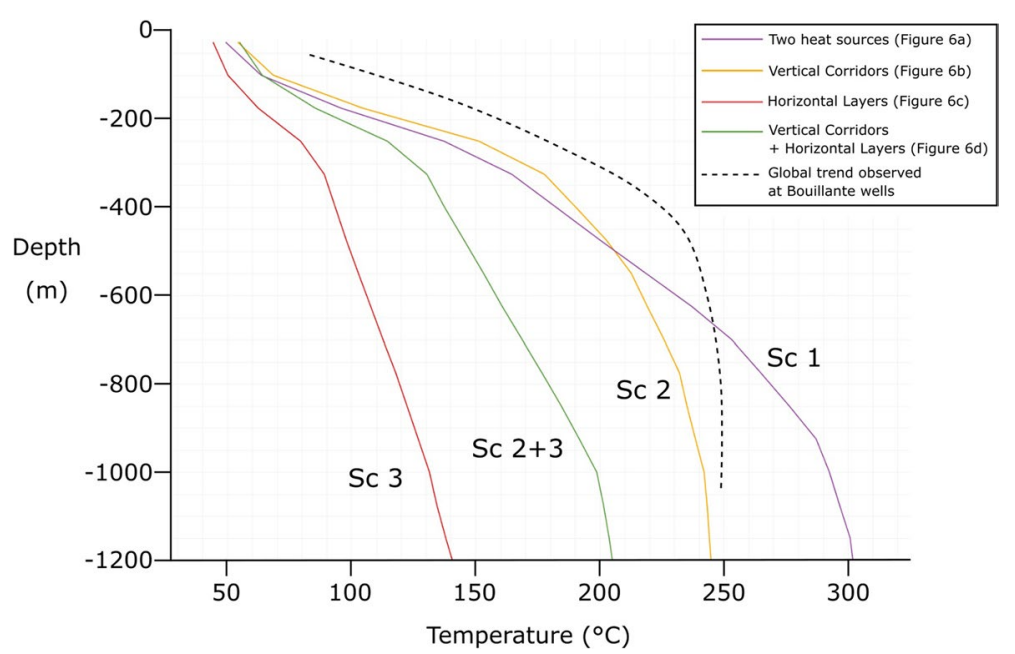

Fig. 7 Temperature profiles extracted for all scenarios after 15,000 years of simulation and compared with data from Bouillante
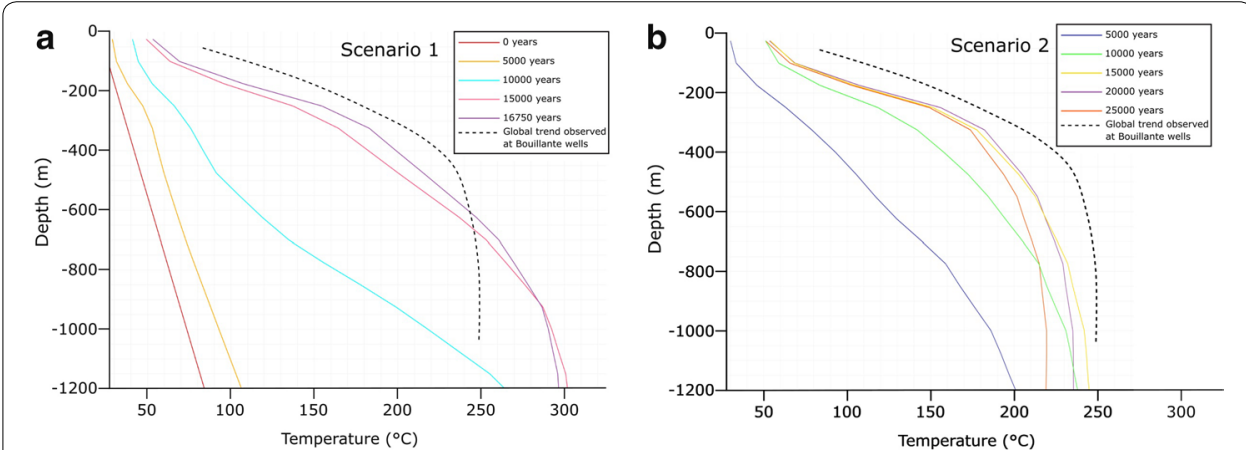

Fig. 8 Temperature profiles extracted at different time stages for two scenarios. a Scenario with a second magmatic heat source. $\mathbf{b}$ Scenario with highly permeable vertical conduits

temperature is reached between 15,000 and 20,000 years of simulation. After that, the temperature decreases and is too low to match the conditions observed at Bouillante.

We returned to the simple single-intrusion setup of Hayba and Ingebritsen (1997) to further explore the sensitivity to matrix permeability. Figure 9 shows the results, displaying temperature-depth curves during the hottest phase of the system for four different matrix permeabilities. A matrix permeability of ca. $8 \cdot 10^{-15} \mathrm{~m}^{2}$ gives an essentially perfect match with the measured values at Bouillante. Even small deviations in permeability would lead to distinctly different temperature profiles, demonstrating that the thermal structure can test model parameterization. Notice, however, that the agreement with the measured temperature profile is also influenced by the geometry of the caprock-here, the caprock was modeled as a simple, 300-m-thick horizontal layer, while in the largescale model it had a mushroom shape.

Varying conduit permeability in the vertical-conduit scenario (Scenario 2) also brings the simulated thermal structure at Bouillante closer to the measured curve. Figure 10 displays the hottest phase of the system for different conduit permeabilities. 


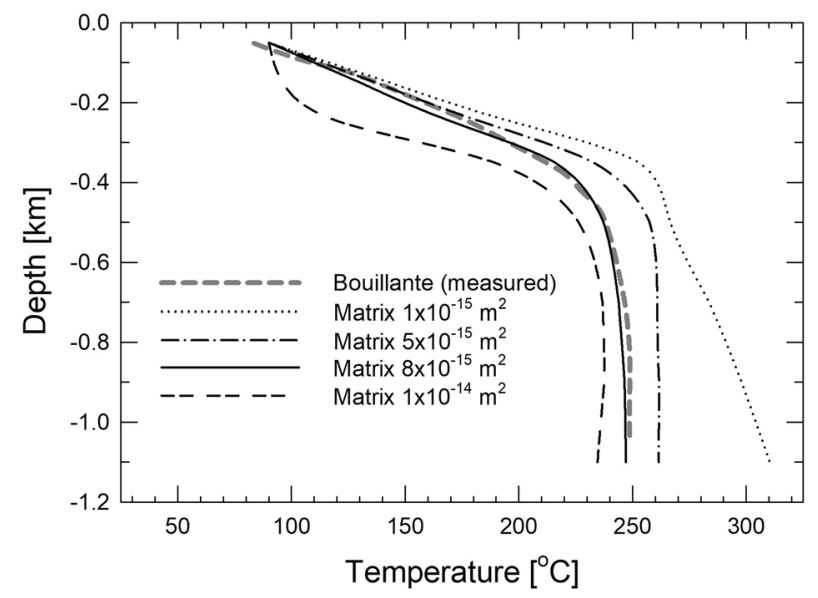

Fig. 9 Temperature-depth curves for a simple model setup following Hayba and Ingebritsen (1997) with a $300 \mathrm{~m}$ thick, horizontal caprock having the same width as the intrusion. The curves represent the onset of the hottest phase in the system's evolution and occur at different times $\left(1 \cdot 10^{-15} \mathrm{~m}^{2}-10,000\right.$ years; $5 \cdot 10^{-15} \mathrm{~m}^{2}$ -7000 years; $8 \cdot 10^{-15} \mathrm{~m}^{2}-4800$ years; $1 \cdot 10^{-14} \mathrm{~m}^{2}-2500$ years)

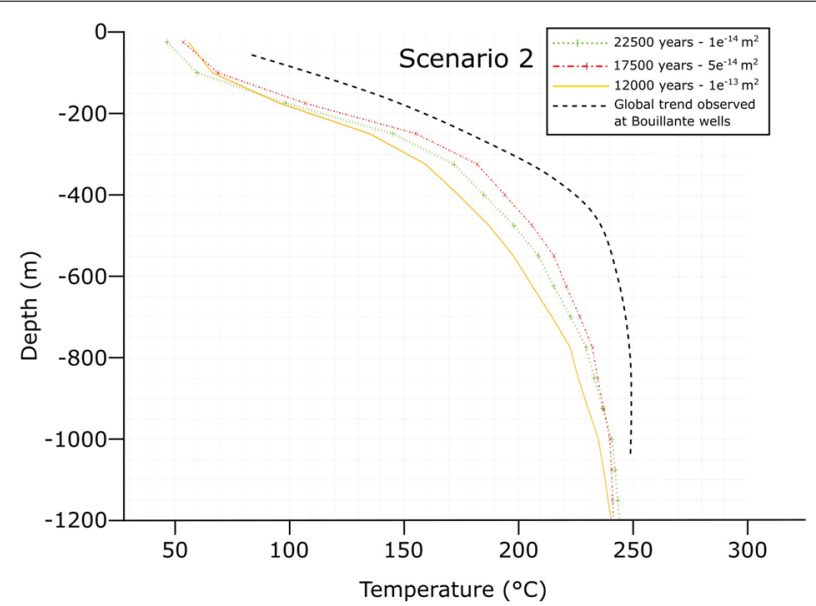

Fig. 10 Temperature profiles extracted for different values of vertical-conduit permeability, at the time of the highest heat flux

A moderate influence of conduit permeability is observed, and conduit permeability also clearly impacts the time at which the highest temperatures are reached. Again, the exact geometry of the vertical conduits and caprocks is expected to influence the result.

\section{Discussion}

The scenarios with a second magma chamber and with permeable vertical conduits both appear capable of explaining the natural thermal anomalies at Bouillante quite well. This finding is not too surprising, as the conduit scenario taps permeable rocks, heated by a high conductive heat flux to temperatures close to those predicted around 
a magma body by the temperature-dependent permeability model of Hayba and Ingebritsen (1997). Without further knowledge of the deep geology of the Island, the distinction between the two scenarios, therefore, remains open.

If the second magmatic heat source scenario is correct, it would imply that the surface geology does not provide a full record of magmatism at Basse-Terre Island. Rather, the simulation predicts that magmatic intrusion occurred ca. 5000 years ago within the 800,000 to 240,000 year old Bouillante magmatic chain. The intrusion age could be older by a few thousand years, as the current thermal profile in the geothermal system could persist for a few thousand years, depending on the size of the intrusion (Driesner and Geiger 2007; Hayba and Ingebritsen 1997) but would still postdate the volcanic rocks in the area by hundreds of thousands of years. This could be further studied by assessing the various possibilities for the size, shape, and location of the magmatic source(s), and the dynamic of these sources, for example by changing the initial conditions to take into account some of the volcanic history, or by including long-distance dyke injections from La Soufrière to Bouillante (Kiryukhin et al. 2018; Sigmundsson et al. 2015).

Our modeling implies that highly permeable lateral layers are unable to transport sufficient heat from La Soufrière to the Bouillante area. Even when combined with highly permeable vertical conduits, the horizontal layers result in a global loss of heat through the lateral boundaries. This effect would likely be amplified in a full 3D model, where topographically driven flow out of our 2D cross section would add to the heat dissipation. This is a strong argument to discard the model that considers large-scale heat transfer from La Soufrière to Bouillante.

\section{Conclusion and perspectives}

We describe numerical modeling constraints on the geothermal hydrology of BasseTerre Island. Identifying those global geological structures that have a potential impact on the physical behavior of the geothermal system, we formulated three possible scenarios and tested the modeling results mainly by assessing their ability to explain temperature anomalies at Bouillante. A key conclusion is that larger-scale heat transfer from La Soufrière magma chamber seems very unlikely to explain geothermal reservoir heat anomalies and particularly the temperature profile measured at Bouillante. Both a second magma chamber beneath the Bouillante geothermal system and high-permeability vertical conduits focusing hot fluids circulating at depth can explain the current system at Bouillante. The scenario with a magmatic intrusion beneath the geothermal system would imply magmatism in this "dormant" part of the island as recently as a few thousand years ago, without identified surface volcanism.

Although this study could not explore the full parameter space-owing to both the lack of further geologic constraints and numerical limitations-it highlights that the physical plausibility of geologically constrained scenarios can, in principle, be tested with current numerical modeling approaches.

\section{Acknowledgements}

This work was performed in the framework of the RING project (http://ring.georessources.univ-lorraine.fr) at Université de Lorraine. Studies were implemented through the program GEOTREF which benefits from the support of both the ADEME and the French public funds "Investments for the future". We would like to thank for their support the industrial and academic sponsors of the RING-GOCAD Consortium managed by ASGA. We also acknowledge Paradigm for providing the SKUA-GOCAD software and API, INRIA for the Geogram library, Pierre Anquez for the SCAR library and Stephan Matthäi for providing the CSMP++ code and API. 


\section{Authors' contributions}

MR built the workflow and tools to create the model, designed the model, ran all simulations on CSMP ++ as well as drafted the manuscript as part of her Ph.D. studies. TD, as project supervisor, provided guidance and insight in evaluating the results, its experience in the use of CSMP++, ran the complementary simulation on Hydrotherm regarding Bouillante site and helped draft the manuscript. FB, as project supervisor, provided guidance and insight in evaluating the results and helped draft the manuscript. All authors read and approved the final manuscript.

\section{Data availability}

The datasets used during the current study are available from the corresponding author on reasonable request.

\section{Competing interests}

The authors declare that they have no competing interests.

\section{Author details}

1 Université de Lorraine, CNRS, GeoRessources, ENSG - 2 Rue du Doyen Marcel Roubault, BP 10162, 54505 Vandoeuvre-lès-Nancy Cedex, France. ${ }^{2}$ ETHZ - Institute of Geochemistry and Petrology, Clausiusstrasse 25, 8092 Zürich, Switzerland.

Received: 17 June 2019 Accepted: 6 September 2019

Published online: 17 September 2019

\section{References}

Anquez P, Pellerin J, Irakarama M, Cupillard P, Lévy B, Caumon G. Automatic correction and simplification of geological maps and cross-sections for numerical simulations. Comptes Rendus Geosci. 2019;. https://doi.org/10.1016/j. crte.2018.12.001.

Besson P, Poirier J-P. The 3100 bp eruption of the soufrière of guadeloupe a transmission electron microscopy study of the cryptodome andesite. Bull Volcanol. 1994;56(3):184-92. https://doi.org/10.1007/BF00279603.

Boudon G, Komorowski J-C, Villemant B, Semet MP. A new scenario for the last magmatic eruption of la soufrière of guadeloupe (lesser antilles) in 1530 a.d. evidence from stratigraphy radiocarbon dating and magmatic evolution of erupted products. J Volcanol Geotherm Res. 2008;178(3):474-90. https://doi.org/10.1016/j.jvolgeores.2008.03.006.

Bouysse P, Westercamp D, Andreieff P. Proceedings of the Ocean Drilling Program, Scientific Results vol. 110. In: Moore JC, Mascle A, editors. The lesser Antilles Island Arc. College Station: Ocean Drilling Program; 1990. https://doi. org/10.2973/odp.proc.sr.110.1990.

Brothelande E, Finizola A, Peltier A, Delcher E, Komorowski J-C, Di Gangi F, Borgogno G, Passarella M, Trovato C, Legendre Y. Fluid circulation pattern inside La Soufrière volcano (Guadeloupe) inferred from combined electrical resistivity tomography, self-potential, soil temperature and diffuse degassing measurements. J Volcanol Geotherm Res. 2014;288:105-22. https://doi.org/10.1016/j.jvolgeores.2014.10.007.

Calcagno P, Bouchot V, Thinon I, Bourgine B. A new $3 \mathrm{~d}$ fault model of the bouillante geothermal province combining onshore and offshore structural knowledge (french west indies). Tectonophysics. 2012;526-529:185-95. https://doi. org/10.1016/j.tecto.2011.08.012.

Driesner T, Geiger S. Numerical simulation of multiphase fluid flow in hydrothermal systems. Rev Mineral Geochem. 2007;65(1):187-212. https://doi.org/10.2138/rmg.2007.65.6.

Feuillet N, Manighetti I, Tapponnier P, Jacques E. Arc parallel extension and localization of volcanic complexes in guadeloupe, lesser antilles. J Geophys Res. 2002;107(B12):3-1329. https://doi.org/10.1029/2001JB000308.

Gaudin D, Finizola A, Delcher E, Beauducel F, Allemand P, Delacourt C, Brothelande E, Peltier A, Di Gangi F. Influence of rainfalls on heat and steam fluxes of fumarolic zones: six months records along the Ty fault (Soufrière of Guadeloupe, Lesser Antilles). JVolcanol Geotherm Res. 2015;302:273-85. https://doi.org/10.1016/j.jvolgeores.2015.06.015.

Guillou-Frottier L. Compilation et analyse des données thermiques sur le champ géothermique de bouillante. premières interprétations pour le fonctionnement du champ géothermique de bouillante. Technical Report BRGM/RP52452-FR, BRGM, Orléans, France. 2003.

Hayba DO, Ingebritsen SE. The computer model Hydrotherm, a three-dimensional finite-difference model to simulate ground-water flow and heat transport in the temperature range of 0 to 1,200 degrees C. Technical Report 94-4045, U.S. Geological Survey; USGS Earth Science Information Center. 1994.

Hayba DO, Ingebritsen SE. Multiphase groundwater flow near cooling plutons. J Geophys Res. 1997;102(B6):12235-52. https://doi.org/10.1029/97JB00552.

Hurwitz S, Kipp KL, Ingebritsen SE, Reid ME. Groundwater flow, heat transport, and water table position within volcanic edifices: implications for volcanic processes in the cascade range. J Geophys Res. 2003;. https://doi. org/10.1029/2003JB002565

Ingebritsen SE, Geiger S, Hurwitz S, Driesner T. Numerical simulation of magmatic hydrothermal systems. Rev Geophys. 2010;48(1):1002. https://doi.org/10.1029/2009RG000287.

Jaud P, Lamethe D. The Bouillante geothermal power-plant, Guadeloupe. Geothermics. 1985;14(2):197-205. https://doi. org/10.1016/0375-6505(85)90061-6.

Kipp KL, Hsieh PA, Charlton SR, Guide to the revised ground-water flow and heat transport simulator: HYDROTHERMVersion 3.T Echniques and Methods 6-A25, U.S. Geological Survey. 2008

Kiryukhin AV, Polyakov AY, Usacheva OO, Kiryukhin PA. Thermal-permeability structure and recharge conditions of the Mutnovsky high-temperature geothermal field (Kamchatka, Russia). J Volcanol Geotherm Res. 2018;356:36-55. https ://doi.org/10.1016/j.jvolgeores.2018.02.010. 
Komorowski JC, Boudon G, Semet M, Beauducel F, Anténor-Habazac C, Bazin S, Hammouya G, Cheminée JL. Guadeloupe. In: Volcanic Atlas of the Lesser Antilles. University of the West Indies, Seismic Research Unit, Trinadad and IAVCEI. 2005. p. 65-102.

Lachassagne P, Marechal JC, Sanjuan B. Hydrogeological model of a high-energy geothermal field (bouillante area, guadeloupe, french west indies). Hydrogeol J. 2009;17(7):1589-606. https://doi.org/10.1007/s10040-009-0486-3.

Laplaige P, Durimel H, Mompelat J-M. Développement de la géothermie dans la Caraïbe. Geosciences. 2013;16:26-35.

Legendre L. Cinématique des déformations fragiles dans la partie Nord de l'arc des Petites Antilles. PhD thesis, Université des Antilles. 2018.

Legendre Y. Reconstruction fine de l'histoire éruptive et scénarii éruptifs à la Soufrière de Guadeloupe: Vers un modèle intégré de fonctionnement du volcan. PhD thesis, Paris 7. 2012.

Magnusdottir L, Finsterle S, iTOUGH2-EOS1SC. Multiphase reservoir simulator for water under sub- and supercritical conditions. User's Guide. Technical Report LBNL-7017E, 1241158. 2015.

Manga M, Hornbach MJ, Le Friant A, Ishizuka O, Stroncik N, Adachi T, Aljahdali M, Boudon G, Breitkreuz C, Fraass A, Fujinawa A, Hatfield R, Jutzeler M, Kataoka K, Lafuerza S, Maeno F, Martinez-Colon M, McCanta M, Morgan S, Palmer MR, Saito T, Slagle A, Stinton AJ, Subramanyam KSV, Tamura Y, Talling PJ, Villemant B, Wall-Palmer D, Wang F. Heat flow in the Lesser Antilles island arc and adjacent back arc Grenada basin. Geochem Geophys Geosyst. 2012;13:8. https://doi.org/10.1029/2012GC004260.

Matthaï SK. Complex Systems Platform, CSMP++, User's Guide. 2014

Matthaï SK, Mezentsev AA, Belayneh M. Finite element-node-centered finite-volume two-phase-flow experiments with fractured rock represented by unstructured hybrid-element meshes. SPE Reserv Eval Eng. 2007;10(06):740-56. https ://doi.org/10.2118/93341-PA.

Navelot V. Caractérisations structurale et pétrophysique d'un système géothermique en contexte volcanique d'arc de subduction Exemple de l'archipel de la Guadeloupe. PhD thesis, Université de Lorraine. 2018.

Navelot V, Géraud Y, Favier A, Diraison M, Corsini M, Lardeaux J-M, Verati C, Mercier de Lépinay J, Legendre L, Beauchamps G. Petrophysical properties of volcanic rocks and impacts of hydrothermal alteration in the Guadeloupe Archipelago (West Indies). J Volcanol Geotherm Res. 2018;360:1-21. https://doi.org/10.1016/j.jvolgeores.2018.07.004.

Paluszny A, Matthäi SK, Hohmeyer M. Hybrid finite element-finite volume discretization of complex geologic structures and a new simulation workflow demonstrated on fractured rocks. Geofluids. 2007;7(2):186-208. https://doi.org/10.1 111/j.1468-8123.2007.00180.x.

Patterson JW, Driesner T, Matthai S, Tomlinson R. Heat and fluid transport induced by convective fluid circulation within a fracture or fault. J Geophys Res. 2018;123(4):2658-73. https://doi.org/10.1002/2017JB015363.

Raguenel M, Bonneau F, Driesner T. Sensitivity analysis on the modeling of flows and heat transfers in the geothermal field of Basse-Terre, Guadeloupe. In: 79th EAGE Conference and Exhibition. 2017. https://doi.org/10.3997/22144609.201701124.

Ricci J, Quidelleur X, Pallares C, Lahitte P. High-resolution K-Ar dating of a complex magmatic system: the example of Basse-Terre Island (French West Indies). J Volcanol Geotherm Res. 2017;345:142-60. https://doi.org/10.1016/j.jvolg eores.2017.07.013.

Rosas-Carbajal M, Komorowski J-C, Nicollin F, Gibert D. Volcano electrical tomography unveils edifice collapse hazard linked to hydrothermal system structure and dynamics. Sci Rep. 2016;6:29899. https://doi.org/10.1038/srep29899.

Samper A. Etude géochronologique, aspects géomorphologiques et géochimiques du volcanisme de lîle de Basse Terre (Guadeloupe), et datation des structures d'effondrement de flanc majeures de I'Arc des Petites Antilles. PhD thesis, Université Paris Sud - Paris XI. 2007.

Scott S, Driesner T, Weis P. The thermal structure and temporal evolution of high-enthal py geothermal systems. Geothermics. 2016:62:33-47. https://doi.org/10.1016/..geothermics.2016.02.004.

Sigmundsson F, Hooper A, Hreinsdóttir S, Vogfjörd KS, Ófeigsson BG, Heimisson ER, Dumont S, Parks M, Spaans K, Gudmundsson GB, Drouin V, Árnadóttir T, Jónsdóttir K, Gudmundsson MT, Högnadóttir T, Fridriksdóttir HM, Hensch M, Einarsson P, Magnússon E, Samsonov S, Brandsdóttir B, White RS, Ágústsdóttir T, Greenfield T, Green RG, Hjartardóttir ÁR, Pedersen R, Bennett RA, Geirsson H, La Femina PC, Björnsson H, Pálsson F, Sturkell E, Bean CJ, Möllhoff M, Braiden AK, Eibl EPS. Segmented lateral dyke growth in a rifting event at Bárðarbunga volcanic system, Iceland. Nature. 2015;517(7533):191-5. https://doi.org/10.1038/nature14111.

Teranov. Rapport de synthèse des études géologiques. Technical report. 2017.

Teranov: Rapport d'interprétation des résultats de modélisation magnétotellurique et gravimétrique, exploration géothermique du PER de Vieux-Habitants, Guadeloupe. Technical Report v.3. 2018

Weis P, Driesner T, Coumou D, Geiger S. Hydrothermal, multiphase convection of $\mathrm{H} 2 \mathrm{O}-\mathrm{NaCl}$ fluids from ambient to magmatic temperatures: a new numerical scheme and benchmarks for code comparison. Geofluids. 2014;14(3):347-71. https://doi.org/10.1111/gfl.12080.

Yapparova A, Matthäi S, Driesner T. Realistic simulation of an aquifer thermal energy storage: effects of injection temperature, well placement and groundwater flow. Energy. 2014;76:1011-8. https://doi.org/10.1016/j.energy.2014.09.018.

Zlotnicki J, Boudon G, Le Mouël J-L. The volcanic activity of la soufrière of guadeloupe (lesser antilles): structural and tectonic implications. J Volcanol Geotherm Res. 1992;49(1-2):91-104. https://doi.org/10.1016/0377-0273(92)90006-Y.

\section{Publisher's Note}

Springer Nature remains neutral with regard to jurisdictional claims in published maps and institutional affiliations. 